\title{
Radioiodination of Sulfhydryl-Sensitive Proteins ${ }^{1}$
}

\author{
Colleen E. Hayes and Irwin J. Goldstein \\ The Department of Biological Chemistry, The University of Michigan, \\ Ann Arbor, Michigan 48104
}

Received January 28, 1975; accepted March 17, 1975

\begin{abstract}
A new procedure is described for the radioiodination of proteins with sulfhydryl groups essential for their biological activity. Aniline is iodinated with ${ }^{125} \mathbf{I}$ labeled sodium iodide in the presence of chloramine- $T$, the product separated by solvent extraction, diazotized and coupled to protein.
\end{abstract}

Radioiodination with ${ }^{125} \mathbf{I}$ has emerged as the method of choice for labeling protein to high specific radioactivity. A number of procedures have been developed to iodinate proteins under mild conditions and with reproducible results $(1-7)$. Of these techniques, none is suitable for the iodination of proteins having thiol groups. Exposure to the oxidants $\mathrm{N}$ chloro- $p$-toluene sulfonamide (chloramine-T) (1), hydrogen peroxide $(2-4)$, iodinemonochloride (5), and iodine itself (7) may result in oxidation of sulfhydryl groups with the concomitant disruption of tertiary structure or the chemical modification of a specific amino acid residue in the active site. An alternative method involves the acylation of protein with $N$-succinimidyl-3-(3-[125I]iodo-4-hydroxyphenyl) propionate (6). However, this active ester could react with cysteinyl as well as lysyl residues and thus also disturb the structural integrity of the protein.

The present report describes a simple, rapid, and reproducible technique for the radioiodination of sulfhydryl-containing proteins to high specific activity. Aniline is iodinated with $\mathrm{Na}\left[{ }^{125} \mathrm{I}\right]$ in the presence of an oxidant, the product separated by solvent extraction, diazotized, and coupled to the protein. This method which was first suggested by Boyd et al. (8) has been applied successfully to the iodination of three proteins known to require cysteinyl residues for full activity.

\section{METHODS}

Protein-iodination-grade $\mathrm{Na}\left[{ }^{125} \mathrm{I}\right](\sim 17 \mathrm{Ci} / \mathrm{mg})$ was purchased from New England Nuclear Corp., Boston, MA; $N$-chloro- $p$-toluene sulfonamide from Eastman Organic Chemicals, Rochester, NY; and aniline, chloroform, and sodium nitrite from J. T. Baker Chemicals, Phil-

1 This study was supported by National Institutes of Health Grant No. AI AM 10171 and Phoenix Project Grant. 
lipsburg. NJ. Bio Gel P-10 was a product of Bio-Rad Laboratories, Richmond, CA. Bandeiraea simplicifolia seeds were obtained from Calbiochem, San Diego, CA. B. simplicifolia lectin, prepared according to Hayes and Goldstein (9), was assayed by hemagglutination of human type B erythrocytes as previously described (9). Phaseolus lunatus component III (lima bean lectin III) was purified and assayed as described by Galbraith and Goldstein (10). Human erythrocytes were supplied by the University of Michigan Blood Bank courtesy of Dr. H. Oberman. Papain, purchased from Worthington Biochemicals, Freehold, NJ, and further purified by affinity chromatography (11), was a gift of Dr. Jules A. Shafer of this University. Papain activity was determined according to Burke et al. (11).

Protein concentration was determined by a microbiuret method using crystalline bovine serum albumin (Metrix, Chicago, IL) as standard (12). Iodinated samples were counted in a total volume of $0.5 \mathrm{ml}$ using a Nuclear Chicago 1185 single channel gamma counter.

Freshly distilled aniline $(10 \mu \mathrm{l})$ was dissolved in $0.1 \mathrm{M} \mathrm{HCl}(100$ $\mathrm{ml})$ and an aliquot $\left(50 \mu \mathrm{l}, 5 \times 10^{-9}\right.$ mole) removed to a 3-ml tapered glass tube containing $0.1 \mathrm{M} \mathrm{HCl}(100 \mu \mathrm{l})$. All subsequent reactions were carried out at $0^{\circ} \mathrm{C}$ unless otherwise noted. $\left.\mathrm{Na}{ }^{125} \mathrm{I}\right](2 \mu 1,1.0 \mathrm{mCi}$, $5 \times 10^{-10}$ mole) was added and the iodination reaction initiated by the addition of freshly prepared $N$-chloro-p-toluene sulfonamide ( $10 \mu \mathrm{l}, 1$ mм, $10^{-8}$ mole). After gentle agitation for $1 \mathrm{~min}$, the solution was adjusted to $\mathrm{pH} 11$ with $1 \mathrm{M} \mathrm{NaOH}$ (indicator paper) and chloroform $(1 \mathrm{ml})$ added. The capped tube was agitated and the chloroform layer removed with a disposable pipet to a second 3-ml tapered glass tube. The extraction was repeated twice more, the combined chloroform extracts evaporated to dryness at room temperature under a gentle stream of nitrogen, and the residue dissolved in $0.1 \mathrm{M} \mathrm{HCl}(100 \mu \mathrm{l})$. Sodium nitrite ( $10 \mu \mathrm{l}, 10 \mathrm{~mm}, 10^{-9}$ mole), added with stirring to the iodoaniline, afforded the diazonium salt which was then slowly dropped into a stirred solution of protein $(10 \mathrm{ml}, 1 \mathrm{mg} / \mathrm{ml})$ at $\mathrm{pH} 10$. After maintaining a $\mathrm{pH}$ of 9-10 for $1 \mathrm{hr}$, dialysis against $0.01 \mathrm{M}$ phosphate buffer $(\mathrm{pH} \mathrm{7.2)}$ with $0.15 \mathrm{M} \mathrm{NaCl}$ or chromatography on a Bio Gel P -10 column $(2.5 \times 30$ $\mathrm{cm})$ equilibrated with the same buffer separated protein from other reaction products.

\section{RESULTS}

Radioiodination of $B$. simplicifolia lectin by a variety of published procedures resulted in the loss of between 64 and $83 \%$ of its type B erythrocyte hemagglutinating activity (Table 1). Since this protein is known to require cysteinyl residues for its carbohydrate-binding activity (9), it was presumed that oxidation to disulfides or cysteic acid residues 
TABLE 1

Iodination of B. simplicifolia Lectin by Published Procedures

\begin{tabular}{lcc}
\hline \multicolumn{1}{c}{ Reference } & $\begin{array}{c}\text { Activity remaining } \\
(\%)\end{array}$ & $\begin{array}{c}\text { Specific activity } \\
(\mathrm{cpm} / \mu \mathrm{g} \text { of protein) }\end{array}$ \\
\hline Hunter and Greenwood (1) & 35 & $8.6 \times 10^{5}$ \\
Marchalonis (2) & 18 & $1.3 \times 10^{3}$ \\
Roholt and Pressman (5) & 17 & $0^{a}$ \\
Syvanen et al. (7) & 36 & $0^{a}$ \\
\hline
\end{tabular}

${ }^{a}$ The reaction was performed with unlabeled NaI.

resulted when the protein was exposed to the oxidants employed. The present technique was developed to circumvent exposure of labile sulfhydryl groups to oxidizing conditions.

As indicated in Table 2, this procedure is suitable for labeling proteins having cysteinyl residues that are required for activity. The hemagglutinating activity of $B$. simplicifolia lectin is completely inhibited by reaction with $\mathrm{Hg}^{2+}$ and dithiobisnitrobenzoic acid (9). This protein was successfully labeled without activity loss by the iodoaniline coupling method. Chromatography of radiolabeled lectin on an affinity column (9) resulted in complete adsorption of both radioactivity and protein. Elution with D-galactose gave a single protein peak with a constant ratio of $A_{280 \mathrm{~nm}}$ to counts per minute throughout the elution peak, indicating that labeled lectin retains its carbohydrate-binding activity and specificity. Results of labeling the lima bean lectin III were similar. Gould and Scheinberg have demonstrated the importance of cysteinyl residues for the binding activity of this lectin and noted partial protection of sulfhy-

TABLE 2

Iodination of Sulfhydryl-Sensitive Proteins with Diazotized Iodoaniline

\begin{tabular}{|c|c|c|c|c|c|c|}
\hline Protein & $\begin{array}{l}\text { Moles } \\
\text { mole } 0\end{array}$ & $\begin{array}{l}\text { f } \mathrm{SH} / \\
\text { orotein }\end{array}$ & $\begin{array}{c}\text { Specific } \\
\text { activity, } \\
\text { native } \\
\text { protein }\end{array}$ & $\begin{array}{c}\text { Specific } \\
\text { activity, } \\
\text { iodinated } \\
\text { protein }\end{array}$ & $\begin{array}{c}\text { Activity } \\
\text { remaining } \\
(\%)\end{array}$ & $\begin{array}{c}\text { Specific } \\
\text { radio- } \\
\text { activity } \\
\text { (cpm } / \mu \mathrm{g} \\
\text { of protein) }\end{array}$ \\
\hline $\begin{array}{l}\text { B. simplicifolia } \\
\text { lectin }\end{array}$ & 4.0 & (9) & $404^{a}$ & 394 & 98 & $1085^{b}$ \\
\hline \multicolumn{7}{|l|}{ Lima bean lectin } \\
\hline III & 3.43 & (13) & $210^{c}$ & 228 & 108 & 1115 \\
\hline Papain & 1.0 & (14) & $72.0^{d}$ & 75.8 & 105 & 760 \\
\hline
\end{tabular}

${ }^{a}$ Type B erythrocyte hemagglutinating titer/mg of protein $/ \mathrm{ml}$.

${ }^{b}$ Average of five experiments.

c Type A erythrocyte hemagglutinating titer/mg of protein $/ \mathrm{ml}$.

a Micromoles of benzoylarginineamide hydrolyzed $/ \mathrm{min} / \mathrm{mg}$ of protein. 
TABLE 3

Specific Radioactivity Obtained with Varying ${ }^{125}$ to Protein Ratios ${ }^{a}$

\begin{tabular}{cccc}
\hline $\begin{array}{c}\text { Protein in } \\
\text { reaction } \\
\text { mixture } \\
(\mathrm{mg})\end{array}$ & $\begin{array}{c}\text { Diazonium } \\
\text { coupling } \\
\text { reaction } \\
\text { volume } \\
(\mathrm{ml})\end{array}$ & $\begin{array}{c}\text { Approxinte } \\
\text { moles of protein/ } \\
\text { mole of }\end{array}$ & $\begin{array}{c}\text { S25 } \\
\text { radioactivity } \\
\text { (cpm/ } / \mu \text { of protein) }\end{array}$ \\
\hline 10 & 10 & 175 & 1085 \\
5 & 5 & 88 & 1982 \\
0.5 & 0.5 & 8.8 & 7109 \\
\hline
\end{tabular}

${ }^{a}$ Experiments were performed using B. simplicifolia lectin.

dryl groups from thiol reagents in the presence of $N$-acetyl-D-galactosamine (13). Labeling with iodoaniline gave a protein with no change in specific hemagglutinating activity.

The sulfhydryl group of papain is at the active site and is required for the enzymatic activity of this enzyme (14). Reaction with diazotized [125I] iodoaniline did not detectably alter its catalytic properties.

By varying the ratio of $\left[{ }^{125} \mathrm{I}\right]$ iodoaniline to protein, the resulting specific radioactivity of the protein could be varied (Table 3 ). It is therefore possible to achieve the approximate degree of radiolabeling desired and adjust the ratio of isotope to protein accordingly.

\section{DISCUSSION}

A variety of biochemical studies makes use of proteins labeled to high specific activity with ${ }^{125} \mathrm{I}$. Metabolic studies, hormone-receptor studies, and radioimmunoassays all depend on the availability of highly radioactive proteins whose biological activity and conformation have not been altered as a result of the labeling process.

The most commonly used radioiodination procedure has been that of Hunter and Greenwood involving direct iodination of tyrosine (and occasionally histidinc) residues in the presence of $N$-chloro- $p$-toluene sulfonamide, a technique that is both rapid and efficient (1). It has been suggested that iodination damage (loss of structural integrity and biological activity) resulting from labeling by this method is caused by impurities in the commercial $\mathrm{Na}\left[{ }^{125} \mathrm{I}\right]$ solution (15). Alternatively, loss of activity may result from exposure of the protein to the oxidant. Other methods employing less severe reaction conditions include the lactoperoxidase-hydrogen peroxide technique of Marchalonis (2). Even in this procedure, however, the protein is exposed to an oxidant, the efficiency of labeling is difficult to control, and a protein contaminant (lactoperoxidase) is introduced into the solution being labeled. In a variation of the Hunter-Greenwood procedure, Syvanen et al. attempted to obvi- 
ate iodination damage by destroying excess oxidant with a change in $\mathrm{pH}$ prior to addition of protein (7). They report a 50\% reduction in labeling efficiency together with a $15 \%$ loss of activity for the enzyme under investigation. The only currently available technique in which neither oxidants nor the commercial $\mathrm{Na}\left[{ }^{125} \mathrm{I}\right]$ solution are included in the iodinating reaction mixture is that of Bolton and Hunter (6). These authors successfully iodinated several protein hormones that are denatured under the conditions of the Hunter-Greenwood method (1). They report, however, that the acylating agent is unstable under the iodination conditions. It would also be expected to acylate thiol groups.

We believe the diazotized iodoaniline coupling procedure reported herein offers an important alternative to existing labeling techniques. It does not involve exposure of protein to oxidants or impurities in commercially available $\mathrm{Na}^{\left[{ }^{125} \mathrm{I}\right.}$ ] nor is the labeling reagent unstable under the reaction conditions used. Furthermore, it may be performed in less than $1 \mathrm{hr}$, gives reproducible results, and is suitable for labeling proteins with reactive thiol groups.

\section{ACKNOWLEDGMENTS}

We thank Mr. Allen Eckhardt of this university for preparing papain samples and assaying papain activity. We also acknowledge the generosity of Dr. J. Pollard and Dr. E. Schantz of Calbiochem in making $B$. simplicifolia seeds available to us. Mr. Tim Ross rendered technical assistance in one phase of this work.

\section{REFERENCES}

1. Hunter, W. M., and Greenwood, F. C. (1962) Nature (London) 194, 495-496.

2. Marchalonis. J. J. (1969) Biochem. J. 113, 299-305.

3. Phillips, D. R., and Morrison, M. (1970) Biochem. Biophys. Res. Commun. 40, 284-289.

4. Hubbard, A. L., and Cohn, Z. A. (1972) J. Cell Biol. 55, 390-405.

5. Roholt, O. A., and Pressman, D. (1972) in Methods in Enzymology (Colowick, S. P., and Kaplan, N. O., eds.), Vol. 25, pp. 438-444, Academic Press, New York.

6. Bolton, A. E., and Hunter, W. M. (1973) Biochem. J. 133, 529-538.

7. Syvanen, J. M., Young, Y. R., and Kirschner, M. W. (1973) J. Biol. Chem. 248, 3762-3768.

8. Boyd, W. C., Bhatia, H. M., Diamond, M. A., and Matsubara, S. (1962) J. Immunol. 89, 463-470.

9. Hayes, C. E., and Goldstein, I. J. (1974) J. Biol Chem. 249, 1904-1914.

10. Galbraith, W., and Goldstein, I. J. (1972) Biochemistry 11, 3976-3984.

11. Burke, D. E., Lewis, S. D., and Shafer, J. A. (1974) Arch. Biochem. Biophys. 164, $30-36$.

12. Janatova, J., Fuller, J. K., and Hunter, M. J. (1968) J. Biol. Chem. 243, 3612-3622.

13. Gould, N. R., and Scheinberg, S. L. (1970) Arch. Biochem. Biophys. 141, 607-613.

14. Sanner, T., and Pihl, A. (1963) J. Biol. Chem. 238, 165-171.

15. Hunter, W. M. (1971) in Radioimmunoassay Methods: European Workshop (Kirkham, K. E., and Hunter, W. M., eds.), pp. 3-23, Churchill Livingstone, Edinburgh and London. 